\title{
A normative basis for EU external relations? Protecting internal values beyond the Single Market
}

\author{
Piet Eeckhout
}

\section{Introduction}

Over the last decade or so, the EU's external policies - now officially and rather inelegantly called "external action" - have grown in ambition, scope and stature. The trajectory is neither unproblematic nor linear. It is clear that some external policies work better than others, and that the EU's constitutional ambition, as expressed in the Treaties, is difficult to realize. The overall tendency is clear, though. The EU - which when it comes to external policies is best understood as a conglomerate of the EU institutions and the Member States - seeks to become an ever more significant global actor, ${ }^{1}$ not just in the economic field but across and beyond the range of its internal competences and policies. Indeed, the fledgling Common Foreign and Security Policy (CFSP) cannot be equated to the external projection of an internal policy; nor is that the case for the EU's external human rights policy.

The Lisbon Treaty was a scarcely veiled attempt to further constitutionalize the founding Treaties. As regards external action, that Treaty clearly constitutes the apex of the EU's constitutional and policy ambition - utopian at best, in the eyes of most. ${ }^{2}$ It is worth recalling here the mere Treaty summary, in Article 3(5) TEU, of what the EU hopes to achieve in the wider world (the full version is in Article 21 TEU):

In its relations with the wider world, the Union shall uphold and promote its values and interests and contribute to the protection of its citizens. It shall contribute to peace, security, the sustainable development of the Earth, solidarity and mutual respect among peoples, free and fair trade,

\footnotetext{
- Faculty of Laws, University College London. This paper is to appear in a collection edited by Prof Markus Krajewski.

${ }^{1} \mathrm{G}$ de Burca, "EU External Relations: The Governance Mode of Foreign Policy", in B Van Vooren, S Blockmans and J Wouters (eds), The EU's Role in Global Governance - The Legal Dimension (OUP 2013) 39, 43.

${ }^{2}$ Or perhaps EUtopian, cf $\mathrm{K}$ Nicolaïdis and R Howse, " 'This is my EUtopia ....: Narrative as Power" (2002) 40 JCMS 767.
} 
eradication of poverty and the protection of human rights, in particular the rights of the child, as well as to the strict observance and the development of international law, including respect for the principles of the United Nations Charter.

It is easy to denigrate such utopian ambition. Yet this is a fundamental Treaty provision, and it is cast in mandatory terms: the EU shall uphold and promote its values and interests. This paper seeks to inquire into the meaning of this Treaty obligation, in particular as regards some of the values generally underpinning the EU's internal market, and the rules and principles concerning services of general interest in particular. It is structured in three parts. The first offers a mapping exercise of the relevant Treaty provisions seeking to establish connections and ways of reading them so that they may "inform" each other. The second puts them in the context of the debate about Normative Power Europe (NPE) - a much used, but not undisputed international relations concept coined to express the nature of the EU's external policies and projection. ${ }^{3}$ The third inquires further into the "normative" nature and effect of the EU's constitutional values and objectives. I will argue that the Treaty normative basis for the EU's external relations is meaningful and is to be taken seriously.

\section{Mapping the Treaties}

Reference was made above to Article 3(5) TEU, which sets out the EU's objectives "in its relations with the wider world". The EU must, first of all, uphold and promote its values. This of course raises the question as to what those values are, and how to define them. Article 2 TEU attempts to sum them up: they are "respect for human dignity, freedom, democracy, equality, the rule of law and respect for human rights, including the rights of persons belonging to minorities". There is no immediate connection here to the values underpinning the internal market, or to services of general interest. There is, however, a mediated one. The EU Charter of Fundamental Rights (EU Charter) contains a series of rights and principles grouped together in a title

\footnotetext{
${ }^{3}$ See the seminal article by I Manners, "Normative Power Europe: A Contradiction in Terms?" (2002) 40 JCMS 235.
} 
on "Solidarity" (Title IV), mostly concerned with social rights, but including Article 36 on "Access to services of general economic interest":

The Union recognises and respects access to services of general economic interest as provided for in national laws and practices, in accordance with the Treaties, in order to promote the social and territorial cohesion of the Union.

This provision is not of course formulated as a human or fundamental right, and the Charter, as is well known, operates a cumbersome distinction between "rights" and "principles". 4 That however cannot mean that Article 36 is not part of the values referred to in Article 2 TEU. The Charter unifies civil and political rights, on the one hand, and social and economic rights on the other. ${ }^{5}$ Its identity is singular: a Charter of Fundamental Rights of the European Union. The distinction between rights and principles is relevant to determining the effects of specific Charter provisions; but it is next to unarguable that, for the purpose of understanding the concept of respect for human rights as a Treaty-determined value of the EU, not all Charter provisions are to be included. It may further be noted that the Charter Title on Solidarity also refers to social security and social assistance (including housing assistance); to a right of access to health care; and to a high level of consumer protection. ${ }^{6}$ The right to education in Article 14 Charter is also worth mentioning.

There are further links between the Treaty provisions on values and objectives, and the promotion of services of general interest. The Charter puts such services under the heading of "solidarity", and Article 2 TEU describes how the EU's "values are common to the Member States in a society in which ... solidarity" (amongst others) prevails. Clearly, the principle of solidarity underpins the EU's concept of what Article 3 TEU describes as "a highly competitive social market economy", and justifies and explains the

\footnotetext{
${ }^{4}$ Art 52(5) EU Charter. See, for an excellent attempt to make sense of that distinction, the Opinion of Crúz Vilalón AG in Case C-176/12 Association de Médiation Sociale EU:C:2013:491, paragraphs 43-80.

${ }^{5}$ Cf D Anderson and C Murphy, "The Charter of Fundamental Rights" in A Biondi, P Eeckhout and S Ripley (eds), EU Law after Lisbon (OUP 2012) 155, 160.

${ }^{6}$ See Artt 34, 35 and 38 EU Charter.
} 
specific place occupied by services of general interest. The principle of solidarity is further expressly referred to as an objective of the EU's external action, in particular in Article 21(1) TEU, which includes it among "the principles which have inspired its own creation, development and enlargement, and which it seeks to advance in the wider world" and which need to guide the EU's action on the international scene.

There is further Treaty confirmation that services of general economic interest form part of the EU's values: Article 14 TFEU expressly confirms this by speaking of "the place occupied by services of general economic interest in the shared values of the Union as well as their role in promoting social and territorial cohesion". Protocol No 26 further elucidates what these shared values entail.

As a last section of this mapping exercise one may point towards the Treaty provisions on the common commercial policy. Both Articles 205 and 207(1) TFEU confirm that the common commercial policy must be conducted in the context of the principles and objectives of the EU's external action. Article 207 TFEU fully extends this policy to trade in services, ${ }^{7}$ and it is of course in the context of international negotiations on such trade that the EU may seek to carve out a special position for services of general interest - both in the EU and elsewhere. This is not a consideration devoid of political and practical relevance in light of the sensitivity of international attempts at liberalizing trade in services in sectors such as water, energy and the like. Another type of sensitivity has found expression in the decision-making provisions of Article 207: by derogation from the standard qualified majority voting, unanimity governs negotiations in the field of trade in cultural and audiovisual services, where they "risk prejudicing the Union's cultural and linguistic diversity"; and in the field of trade in social, education and health services, where they "risk seriously disturbing the national organisation of such services and prejudicing the responsibility of Member States to deliver them".

\footnotetext{
${ }^{7}$ See eg M Krajewski "The Reform of the Common Commercial Policy" in Biondi, Eeckhout and Ripley (n 5 above) 292, 300.
} 
It may be useful to sum up the main findings of this mapping exercise:

- in its external action the EU is subject to an obligation to uphold and promote its own values;

- those values include respect for human rights in a society in which solidarity prevails;

- the EU Charter lists access to services of general economic interest as a fundamental right, under the heading of solidarity;

- the principle of solidarity must be promoted as one of the express goals of EU external action;

- the EU's internal market is described as a highly competitive social market economic and services of general economic interest are part of it, occupying a place in the shared values of the EU;

- EU exclusive competence extends to international trade in services, but the decision-making provisions recognize that the liberalization of certain services is sensitive; and the common commercial policy must respect the principles and objectives of EU external action.

Taken together, these Treaty provisions confirm that services of general interest are part of the EU's values system. Precisely what that means, in substantive terms, is beyond the scope of this paper, as it would require an analysis of its own. It is clear though that, in its external action, the EU must take services of general interest into account. That Treaty command can be seen as a requirement for the EU's external dealings (for example when negotiating the liberalization of trade in services) not unduly to interfere with how services of general interest are organized within the EU Member States. But it could also be seen as a duty to respect and protect such services elsewhere, in third countries.

Further reflection is of course needed on the normative "thickness" of the Treaty command for the EU to respect and promote its values in its external action. What does this normativity entail? Can it be operationalized, or is it no more than a form of constitutionalized wishful thinking? A small detour via 
international relations theory may assist in this reflection.

\section{Normative Power Europe?}

Many legal scholars are generally critical of the attempt to constitutionalize the EU's values and objectives. As Larik reports, the manifold codified objectives of the EU have been described as a "Christmas tree" (in particular by the British delegation to the Convention on the Future of Europe), or a "hodgepodge" (von Bogdandy); or, specifically in relation to external objectives, as "redolent of motherhood and apple pie" (Dashwood and others), or a wish list for a better world (Drescher). ${ }^{8}$ Even if he does not at length address the EU's external objectives, de Witte also complains that there is too much constitutional law in the EU's foreign relations. ${ }^{9}$

These scholars either regard the constitutionalization of values and objectives as rather meaningless, because of their vagueness and level of abstraction; ${ }^{10}$ or as hopelessly idealistic for the cold world of foreign relations, thereby placing themselves in the realist camp of international relations commentators. De Witte's critique is of a different character: he worries about the level of entrenchment which the law of EU external relations suffers through the process of constitutionalization.

On the other hand, Larik argues that the EU's tendency to provide for a constitutional casting of the EU's external objectives is by no means unique, in that there is a general trend towards what he calls a "dynamic

\footnotetext{
${ }^{8} \mathrm{~J}$ Larik, "Entrenching Global Governance: The EU's Constitutional Objectives Caught Between a Sanguine World View and a Daunting Reality", in B Van Vooren, S Blockmans and J Wouters (eds), The EU's Role in Global Governance - The Legal Dimension (OUP 2013) 7 , 18.

${ }^{9} \mathrm{~B}$ de Witte, "Too Much Constitutional Law in the European Union's Foreign Relations?", in M Cremona and B de Witte (eds), EU Foreign Relations Law - Constitutional Fundamentals (Hart Publishing 2008) 3.

${ }^{10}$ See also P Leino, "The Journey Towards All that is Good and Beautiful: Human Rights and 'Common Values' as Guiding Principles of EU Foreign Relations Law", in Cremona and de Witte (n 9 above) 259, 265.
} 
internationalization" in constitutional law. ${ }^{11}$ Many States' constitutions, both in Europe and beyond, ${ }^{12}$ are said to follow the same trend.

It is however remarkable that the general scepticism among lawyers is not shared by an important strand in international relations scholarship on the EU. Ian Manners' article on Normative Power Europe (NPE) is clearly seminal, and was shortlisted by the Journal of Common Market Studies as one of the 5 best papers of the 2002-2011 decade. ${ }^{13}$ The article was published in the first half of 2002, at a time when the Convention on the Future of Europe was only beginning to meet, and had not even started to debate how to constitutionalize the EU's external action. And yet much of what Manners said about NPE is reflected in the provisions of the Constitutional Treaty and of the Lisbon Treaty.

It is not the purpose of this paper to offer a full analysis of the concept of NPE, and the debate pertaining to it among international relations scholars. I should merely like to note the remarkable convergence between this concept and the process of constitutionalization of the EU's values and objectives, in the sphere of its external action. This convergence can be illustrated with a brief aperçu of some of Manners's observations, analyses and concepts, as set out in his seminal article. His main aim was to move away from the dichotomy between military and civilian power, as it had been applied to the EU's external policies. He claimed that "by refocusing away from debate over either civilian or military power, it is possible to think of the ideational impact of the EU's international identity/role as representing normative power". ${ }^{14} \mathrm{He}$ argued that one of the problems with the notions of civilian and military power was "their unhealthy concentration on how much like a state the EU looks" and considered that they "need to be augmented with a focus on normative power of an ideational nature characterized by common principles and a

\footnotetext{
${ }^{11} \mathrm{~J}$ Larik, Shaping the international order as a Union objective and the dynamic internationalization of constitutional law, CLEER Working Papers 2011/5, $9 \mathrm{ff}$.

${ }^{12}$ Larik (n 8 above) 12-14.

${ }^{13}$ I Manners, "Normative Power Europe: A Contradiction in Terms?" (2002) 40 JCMS 235. On the nomination, see the journal's website at http://onlinelibrary.wiley.com/journal/10.1111/\%28ISSN\%291468-5965.

${ }^{14}$ Ibid at 238.
} 
willingness to disregard Westphalian conventions". ${ }^{15}$ The EU's normative difference was argued to come from its historical context, hybrid polity and political-legal constitution. ${ }^{16}$ Its constitutional norms were said to represent crucial constitutive factors determining its international identity, and the three above factors "accelerated a commitment to placing universal norms and principles at the centre of its relations with its Member States ... and the world ... ." Manners argued that "we cannot overlook the extent to which the $\mathrm{EU}$ is normatively different to other polities with its commitment to individual rights and principles in accordance with the ECHR and the UN". ${ }^{17} \mathrm{He}$ rejected the assumption that normative power requires a willingness to use force in an instrumental way, instead contending that "the central component of normative power Europe is that it exists as being different to pre-existing political forms, and that this particular difference pre-disposes it to act in a normative way". ${ }^{18}$

Again, all of this was written prior to the drafting of the Constitutional Treaty and the Treaty of Lisbon. However, Manners's analysis was not confined to defining the concept of normative power in the rather abstract sense above. He digged deeper into the EU's normative foundations, identifying five "core" norms within the acquis communautaire and the acquis politique. Those norms, he argued, were (1) the centrality of peace; (2) the idea of liberty; (3) democracy; (4) the rule of law; and (5) respect for human rights and fundamental freedoms. He further suggested four "minor" norms, but admitted that they were much more contested. Those norms were (1) social solidarity, (2) anti-discrimination, (3) sustainable development and (4) good governance. ${ }^{19}$

The convergence between this normative basis and the current TEU provisions setting out the EU's values and objectives is striking. Of course, Manners did not pick these core and minor norms out of thin air; except for

\footnotetext{
${ }^{15}$ Ibid at 239.

${ }^{16} \mathrm{lbid}$ at 240 .

$17 \mathrm{lbid}$ at 241 .

${ }^{18} \mathrm{lbid}$ at 242 .

${ }^{19}$ lbid at 242-243.
} 
the centrality of peace, the core norms were all referred to in Article 6 TEU, post Nice. However, the Lisbon Treaty has clearly built on the NPE concept, and its provisions are arguably closer to Manners's concept and normative basis analysis than previous Treaty versions. The point is not to show that the Treaty drafters embraced the NPE concept - though to some extent there may have been some influence. ${ }^{20}$ Nor is it to argue that NPE is undisputed, ${ }^{21}$ or that Manners' seminal article has exhausted the reflection on NPE.

However, what the NPE literature does show is that the constitutionalization of the EU's values and objectives corresponds to conceptions widely held in international relations scholarship about the specificity of the EU's international identity. From this perspective, the Treaty catalogue of values and objectives cannot so easily be discarded as unrealistic, idealist, unspecified and vague; or as simply comparable to national constitutions, or constituting excessive constitutionalization. It is worth quoting one of Manners's final paragraphs: ${ }^{22}$

The concept of normative power is an attempt to suggest that not only is the EU constructed on a normative basis, but importantly that this predisposes it to act in a normative way in world politics. It is built on the crucial, and usually overlooked observation that the most important factor shaping the international role of the EU is not what it does or what it says, but what it is. Thus my presentation of the EU as a normative power has an ontological quality to it - that the EU can be conceptualized as a changer of norms in the international system; a positivist quantity to it - that the EU acts to change norms in the international system; and a normative quality to it - that the EU should act to extend its norms into the international system.

Further literature on NPE has shown, however, that the concept of normative power is not straightforward - at least not for international relations scholars. The debate is in large measure about the meaning of "normative". ${ }^{23}$ One question is the extent to which "normative" stands for universal norms and principles. Aggestam, for example, sees tension in EU foreign policy

\footnotetext{
${ }^{20}$ Cf T Forsberg, "Normative Power Europe, Once Again: A Conceptual Analysis of an Ideal Type" (2011) 49 JCMS 1183, 1186, where he refers to the adoption of NPE in policy papers and public diplomacy.

${ }^{21}$ For an overview of the criticism, see ibid at 1187-1189.

${ }^{22}$ Manners (n 13 above) at 252.

${ }^{23}$ Forsberg (n 20 above).
} 
discourse between universalist aspirations and attempts to shape the world in Europe's image. ${ }^{24}$ She prefers focusing on the extent to which the EU is an ethical power, because that puts greater emphasis on questions of agency. ${ }^{25}$ According to De Zutter, there is no need for a normative power to advocate and diffuse universal norms; normative power is an identity attributed to a political entity that diffuses its own norms in the international system. ${ }^{26}$ However, such a conception of normative power would extend it to other international actors (States) - an express aim of De Zutter's analysis - and thereby dilute the idea that the EU is different. Manners, by contrast, continues to focus on universal norms and on the extent to which the EU "acts in a normative (i.e. ethically good) way". ${ }^{27}$ De Wekker and Niemann argue that the emphasis placed on law is an indicator of normative power: "A true normative power would bind not only others but also itself to collective rules". 28 Again, however, it could be said that there are many other international actors which aim to exercise such normative power.

It is in this reflection on normative power that legal doctrine and scholarship may be able to assist, as notions of normativity are at the heart of law and legal systems. Put simply, the normativity of NPE could be regarded to be constitutionally normative, in the legal sense: the EU is required to act externally in accordance with its own constitutionally determined normative basis, i.e. its values and objectives. In Manners's terms, that idea would not answer the positive question - whether the EU acts as a normative power. But it is highly relevant to the ontological and normative questions - whether the EU is a normative power, and whether it ought to act as one. Furthermore, legal doctrine and scholarship may also assist in further defining the concept of "normative" in NPE, and in identifying the relevant norms as well as reflecting about their universal or universalizable character. It would for

\footnotetext{
${ }^{24}$ L Aggestam, “Introduction: Ethical power Europe?” (2008) 84 International Affairs 7. ${ }^{25}$ Ibid, 3.

${ }^{26} \mathrm{E}$ De Zutter, "Normative power spotting: an ontological and methodological appraisal" (2010) 17 Journal of European Public Policy 1107.

27 I Manners, "The normative ethics of the European Union" (2008) 84 International Affairs 45.

${ }^{28} \mathrm{~T}$ de Wekker and A Niemann, "EU relations with Moldova: normative power Europe in action?" European Foreign Policy Unit Working Paper No 2009/3, available at http://www.Ise.ac.uk/internationalRelations/centresandunits/EFPU/EFPUpdfs/EFPUworkingpa per2009-3.pdf, 13.
} 
example be useful to start building bridges between the NPE literature and the literature on constitutionalism, European and international.

Much of this is beyond the scope of the present paper. The following section offers some initial ideas about the normative character of the EU's values and objectives.

The nature and effect of the EU's values and objectives as norms for external action

From a legal perspective, the analysis of the nature and effect of the EU's values and objectives naturally starts with some inquiry into their enforceability. The focus of that inquiry immediately turns on the EU Court of Justice (CJEU): to what extent is it possible to enforce, judicially, respect for the EU's fundamental norms in its external action. This immediate focus on the CJEU is a near Pavlovian reflex for EU legal scholars, and ought to be questioned, or at least contextualized.

To begin with, it is not obvious that litigation before the EU's own court would constitute a meaningful form of enforceability of the EU's values and objectives. In particular as regards external action, it could be argued that genuine enforcement ought to be located at the international judicial level, because of the stronger guarantees of independence offered by an "external" judiciary. However, there are few avenues at present for such external judicial control, though that may change once the EU joins the European Convention on Human Rights (ECHR).

There may be further concerns as to the relevance of internal, CJEU judicial control. There may well be a gap between the concept of enforceability, and its practical relevance. It may be easy to show that, in principle, respect for the EU's values and objectives is judicially enforceable; but whether such enforceability makes an empirically demonstrable contribution to such respect is another matter. Questions may also arise as to the "thickness" of 
enforceability, and the potential for tension between the different values and objectives. Is not their general character such that their enforceability may not be very meaningful for hard decisions and the daily practice of external action.

But even with those questions and doubts in mind, the inquiry into judicial enforceability before the CJEU continues to be useful, for a number of reasons. One of those is that the strong rule-of-law dimension of the EU is not just a lofty ideal which the Treaties uphold, but is a reality in day-to-day policy-making. Disagreements between the institutions, or between the Member States and the institutions, or between private parties and the institutions or Member States, quickly assume a strong legal dimension, and are easily judicialized. In the sphere of EU external relations law, many such disputes have a significant constitutional dimension: they may concern the division of competences between the EU and its Member States; ${ }^{29}$ matters of legal basis determining the respective powers of the institutions; ${ }^{30}$ the constraints imposed by the duty of cooperation between the EU institutions and the Member States; ${ }^{31}$ or the protection of fundamental rights in the context of counter-terrorism policies. ${ }^{32}$ The phenomenon of which de Witte complains - that there is too much constitutional EU external relations law ${ }^{33}$ is to some degree a function of this strong rule-of-law dimension, and therefore unavoidable. That is not to say that all of the case law excels in terms of constitutional quality and rigour. The critique that some of the judgments may be too complicated may well be justified. But the blame of judicialization, also of EU external policies, cannot be laid at the door of the CJEU: it is a function of the detailed and prolific Treaties which the Member States have drafted; of the wide scope of EU external action, in particular of a normative kind (it is no accident that so-called smart sanctions constitute the core of the CFSP); and of the EU's strong rule-of-law dimension. It may be added that the actual judgments of the CJEU are but the tip of the iceberg.

\footnotetext{
${ }^{29}$ For a recent example, see Case C-414/11 Daiichi Sankyo EU:C:2013:520, regarding the scope of the extension of the common commercial policy to intellectual property.

${ }^{30}$ See eg Case C-130/10 EP v Council EU:C:2012:472, regarding the EP's involvement in counter-terrorist asset freezing measures.

${ }^{31}$ See eg Case C-246/07 Commission v Sweden (PFOS) EU:C:2010:203.

${ }^{32}$ See eg Joined Cases C-584/10 P, C-593/10 P and C-595/10 P Commission, UK and Council v Kadi (Kadi II) EU:C:2013:518.

${ }^{33}$ de Witte (n 9 above).
} 
Beneath the surface there is a panoply of legal opinions and advocacy nourished by the principles developed in the case law. In this basic sense, of extensive judicialization, there is a strong normative dimension to EU external action.

There is not much case law yet on the EU's values and objectives, in relation to external action - particulary in their Lisbon version, which for case law purposes is still quite young. Even so, there are some episodes and instances which clearly exemplify the potential for such case law to develop, and to determine the meaning of those values and objectives, and of the obligation to respect and promote them. Three of those episodes/instances are summarily recounted below. Two of them concern the requirement to respect fundamental rights; the third concerns the mandate to respect international law.

The first episode revolves around the EU's external human rights policy, more specifically the policy to include human-rights clauses in bilateral agreements which the EU concludes with third countries. ${ }^{34}$ Those clauses were initially a response to difficulties which the (then) EC had with suspending development aid to ACP countries with regimes which grossly violated human rights, and with suspending the cooperation agreement with Yugoslavia at the time of conflict between the Yugoslav republics. In the latter case, there was litigation before the Court of Justice: a German wine importer, Racke, challenged the suspension of the agreement in response to the actions of the then Serbian regime and the attendant re-introduction of customs duties. The Court found in favour of the Council, which had suspended the agreement invoking the rather precarious rebus sic stantibus doctrine of customary international treaty law. ${ }^{35}$ Despite this successful defence the institutions acknowledged that there was a legal need to provide for the possible suspension of free trade,

\footnotetext{
${ }^{34}$ See eg $\mathrm{F}$ Hoffmeister, Menschenrechts- und Demokratieklauseln in den vertraglichen Aussenbeziehungen der Europäischen Gemeinschaft (Springer 1998); K Arts, Integrating Human Rights into Development Cooperationn: The Case of the Lomé Convention (Kluwer Law International 2000); E Fierro, The EU's Approach to Human Rights Conditionality in Practice (Martinus Nijhoff 2003); L Bartels, Human Rights Conditionality in the EU's International Agreements (OUP 2005).

${ }^{35}$ Case C-162/96 Racke v Hauptzollamt Mainz EU:C:1998:293.
} 
cooperation and association agreements in cases of systemic violations of human rights. This need strongly contributed to what became a core component of the EU's external human rights policy: the requirement to include so-called "essential elements" clauses in bilateral agreements requiring the parties to respect fundamental rights. It is a policy which stands to this day, and which is not always convenient: witness the foundering of negotiations with Australia because of that country's refusal to accept such a clause. ${ }^{36}$ It is further clear that the policy is not just a response to the legal difficulties which the Racke case revealed - the institutions deserve more than just defensive credit, and the European Parliament in particular has always been a strong advocate for a meaningful external human rights policy. But it is equally obvious that the case law has assisted in crystallising the issues and has made a meaningful contribution.

The second episode is well known, and has given rise to an enormous amount of debate: the Kadi saga, which concerns the EU implementation of UN counter-terrorism policies and the requirement for the EU institutions to respect the fundamental rights of those suspected of supporting terrorism. The saga has now come to an end with the de-listing of Mr Kadi, a Saudi businessman, by the UN Security Council, and with the double victory he scored in the CJEU. ${ }^{37}$ It is again an episode confirming the importance of the protection of fundamental rights in the EU's external action. Even in the face of a binding UN Security Council Resolution, the EU institutions must ensure that the listed person's rights of defence, of effective judicial protection, and to property are respected. It does not matter that the listed person is not a national of one of the Member States, and resides outside the EU: as a person subject to EU law by virtue of the freezing of his EU assets, Mr Kadi could claim the full protection of his EU law fundamental rights.

This dimension of the Kadi litigation, which has received very little commentary, is particularly noteworthy for the NPE debate. The protection of

\footnotetext{
${ }^{36}$ Fierro (n 34 above) at 287-302.

37 Joined Cases C-402 and 415/05 P Kadi and Al Barakaat (Kadi I) EU:C:2008:461; for an overview of some of the relevant literature on this judgment see S Poli and M Tzanou, "The Kadi Rulings: A Survey of the Literature" (2009) 28 YEL 533; Kadi II (n 28 above).
} 
a person's human rights does not stop at the EU border; nor is it reserved to EU citizens. This approach, which is in consonance with the ECHR, builds a strong link between the EU Charter of Fundamental Rights and EU external action. It is highly relevant to EU policies on economic and financial sanctions, which are not confined to counter-terrorism, and which are currently under constant and intense judicial scrutiny in Luxembourg. But the link may be equally relevant to the EU's treaty-making practice, as the debate leading to the European Parliament's rejection of the Anti-Counterfeiting Trade Agreement (ACTA) has shown. ${ }^{38}$ It is worth noting that the Commission tried to defuse that debate by requesting an Opinion from the CJEU, pursuant to Art 218(11) TFEU, on the compatibility of ACTA with the EU system of fundamental rights protection. ${ }^{39}$ The request was later withdrawn, in the face of the Parliament's firm rejection, but nevertheless showed the potential for litigation on respect for human rights when the EU negotiates a trade agreement.

It is true that the Kadi episode also exposes the potential for tension between the requirement to uphold the protection of fundamental rights and the objective of ensuring "the strict observance and the development of international law, including respect for the principles of the United Nations Charter" (Article 3(5) TEU). Clearly, the EU's values and objectives will not always coexist as harmoniously as one would like. However, there is a reading of the Kadi saga which leaves room for some level of harmony. The protection and promotion of human rights is a UN objective, as much as it is an EU objective. The judgment in Kadi I led to a remarkable improvement in the UN's review system for counterterrorism listings, through the creation of the office of the Ombudsperson. This is NPE at work. The EU judicial challenge to the UN Security Council's practices focused attention on improving them, and led to a much stronger normative focus. It may further be noted that in its latest judgment the Court of Justice claims that judicial review of counterterrorism listings "is indispensable to ensure a fair balance

\footnotetext{
${ }^{38}$ See D Matthews and P Zikovská, "The Rise and Fall of the Anti-Counterfeiting Trade Agreement (ACTA): Lessons for the European Union" (2013) 44 IIC 626.

${ }^{39}$ Opinion 1/12, see [2013] OJ C 123, p. 14.
} 
between the maintenance of international peace and security and the protection of the fundamental rights and freedoms of the person concerned ..., those being shared values of the UN and the European Union". ${ }^{40}$ The Court thus strongly contributes to an international projection of the EU as a valueoriented actor, and advocates a similar conception for, and an allegiance with, the UN.

The third instance concerns one of the first judicial applications of the new provision in Article 3(5) TEU - also relevant to the Kadi litigation - requiring the EU to promote the strict observance and the development of international law. In the litigation concerning the extension of the EU's emissions trading legislation to air transport (which, incidentally, can be seen as a tool to promote sustainable development, another objective of external action), the Court of Justice referred to Article 3(5) TEU in relation to the capacity of US airlines to rely on customary international law. ${ }^{41}$ The airlines' challenge was unsuccessful, and the judgment was not the first in which the Court applied customary international law. ${ }^{42}$ Those qualifications notwithstanding, it is definitely not excluded that the Court may display a greater willingness to hear international law arguments and become stricter in upholding the international rule of law, including against the EU's own institutions. The indicia are limited at this point in time, though, and what is stated here constitutes more a personal prediction than an established tendency.

These episodes/instances are exemplary rather than determinative. Some tentative conclusions can be drawn from them, but a more structured analysis of the normative dimension of the EU's values and objectives requires further reflection. It is nevertheless clear that the examples given are in line with the NPE concept. They show the legal significance of these values and objectives, often at the detriment of effective, purely interest-based external policies. It would be more straightforward to negotiate bilateral agreements if there was no need to include an essential elements clause. The EU's

\footnotetext{
${ }^{40}$ Kadi II, paragraph 131.

${ }^{41}$ Case C-366/10 Air Transport Association of America EU:C:2011:864.

${ }^{42}$ See also Racke (n 35 above).
} 
counter-terrorism and other sanctions policies would be easier to implement if the EU institutions could simply hide behind the Security Council. And the EU's legislative agenda is not inviting the constraint of international law.

The episodes narrated here also exemplify the scope for judicial enforcement of the EU's values and objectives, as well as indicating ways in which the case law of the CJEU may contribute to NPE by, for example, requiring respect for fundamental rights and for international law, and by instituting normative dialogue with other actors such as the UN Security Council.

\section{Some concluding remarks}

The argument that the EU is primarily a normative power predates the strong constitutionalization of the EU's values and objectives through the Lisbon Treaty. Nevertheless, that constitutionalization invites a further reflection about the normativity of these values and objectives. The NPE literature is a useful backdrop for this reflection, which ought to conducted also by legal scholars, who should take those values and objectives more seriously than has so far been the case. This paper has attempted to offer a first start, by focusing on normativity from a perspective of judicial enforceability. The preliminary conclusion is that the EU's values and objectives are meaningful to judicial discourse, and have some degree of enforceability.

This paper has not focused much on services of general economic interest, in contrast with the remainder of this volume. It is clear though that the EU's conception of such services is embedded in its value system, as confirmed by the Treaties and by the Charter. This means that the protection and, conceivably, the exportation of that conception need to be taken on board in the EU's external action. The identification of social solidarity as a norm which NPE embraces, confirms that finding.

That raises further questions about the nature of the norms which ought to promote and diffuse in its external action. Is the recognition and protection of 
services of general economic interest a universal norm, or is it rather a typical, internal EU norm, which the EU seeks to export? That question can also be raised with respect to other norms which form part of the EU's fundamental values system. But it is not clear whether the NPE concept requires absolute universality, as distinguishable from a concept of fundamental norms, and a fundamentally normative approach, focusing on Europe's conception of the good life; norms lending themselves to universal application without constituting the emanation of a new form of imperialism. 